\title{
A Formaldehyde-free Adhesive for Particleboards Based on Soy Flour, Magnesium Oxide, and a Plant-derived Enzymatic Hydrolysate
}

\author{
Francesco Balducci, ${ }^{\mathrm{a}}$ Stergios Adamopoulos, ${ }^{\mathrm{b}, *}$ Claudio Pettinari, ${ }^{\mathrm{c}}$ Enrico Canti, ${ }^{\mathrm{d}}$ \\ Corrado Di Nicola, ${ }^{c}$ Alessia Tombesi, ${ }^{c}$ Alessandra Cecchini, ${ }^{a}$ and Christian Gabbani ${ }^{\text {e }}$
}

\begin{abstract}
An adhesive for particleboards based on natural materials was prepared. Soy flour (38.9 wt\%), magnesium oxide (MgO) (2.8 wt\%), and a hydrolysate from an agricultural crop (13.9 wt\%) were mixed with water and ground in a ball mill at $44 \%$ solids. The solubility and interaction of the soy flour proteins and the proteins contained in the plant hydrolysate were triggered by the strong basic environment created by $\mathrm{MgO}$ in the presence of water. The natural adhesive appeared to be thermally stable at temperatures from $130^{\circ} \mathrm{C}$ to $240^{\circ} \mathrm{C}$, with unchanged mass and no major signals in the thermal analysis curves. These results, together with a viscosity of $510 \mathrm{~Pa} \cdot \mathrm{s}$ at $25^{\circ} \mathrm{C}$, suggested a good operability of the adhesive. Three-layered particleboards were manufactured with weight combinations of natural adhesive and polyamidoamine-epichlorohydrin (PAE) of $0 \%: 100 \%, 33 \%: 67 \%, 50 \%: 50 \%, 67 \%: 33 \%$, and 100\%:0\%. The natural adhesive showed inferior internal bond strength and poor water resistance compared with urea-formaldehyde-bonded boards. Addition of the PAE significantly improved the internal bond and swelling, and for all the combinations these properties were comparable or, in most cases, better than in the urea-formaldehyde controls. All boards were formaldehyde-free, while the natural adhesive itself released no dangerous volatile substances.
\end{abstract}

Keywords: Protein adhesives; Natural materials; PAE; Viscosity; DSC; TGA; Formaldehyde; Internal bond; Thickness swelling; Wood composites

Contact information: a: Manifaktura s.r.l., Via del Carso n.27, 61121 Pesaro, Italy; b: Department of Forestry and Wood Technology, Linnaeus University, Lückligs Plats 1, 35195 Växjö, Sweden; c: Scuola di Scienze del Farmaco e dei Prodotti della Salute, Università di Camerino, Via S. Agostino 1, 62032

Camerino, Italy; d: NIS S.r.l., Via Leonardo da Vinci 46, 61022 Vallefoglia (PU), Italy; e: Cosmob S.p.A., Via della Produzione 61, 61025 Montelabbate (PU);

*Corresponding author: stergios.adamopoulos@lnu.se

\section{INTRODUCTION}

Presently, the particleboard industry uses almost exclusively urea-formaldehyde (UF) resins (Eastin et al. 2015). However, environmental sustainability and consumer demand for healthier products have contributed to increasing research efforts to find substitutes for these petroleum-based thermosetting adhesives. Formaldehyde was reclassified as a human carcinogen by the International Agency for Research on Cancer in 2004 (IARC 2006), while a new classification entered into force for the European Union in June 2014, following the Commission Regulation (EU) 2015/491 on classification, labelling and packaging of substances and mixtures (CLP Regulation). The discussions on both the availability of fossil resources for producing millions of tons of amino resins every year and the restrictions on formaldehyde emissions from finished wood composite 
products are expected to intensify (Salthammer et al. 2010; Hemmilä et al. 2019a). The US Environmental Protection Agency (EPA) adapted the California Air Resources Board (CARB) emission limits in 2017 (EPA 2017), and formaldehyde in indoor environments is a current legislative topic around the world. The latest example is in Germany, where decreased legal limits for formaldehyde emissions (from the European emission level E1 of $0.10 \mathrm{ppm}$ to $0.05 \mathrm{ppm}$ ) and a new proposed test method will come into effect on 1 January 2020. The relevant notice (Bundesanzeiger, BAnz, AT 26.11.2018 B2) of the German Federal Ministry for the Environment, Natural Conservation and Nuclear Safety (Bundesministerium für Umwelt Naturschutz und nukleare Sicherheit, BUM) has been published recently in the Federal Register (BUM 2018).

Adhesives based on alternative, renewable resources can satisfy the need for formaldehyde-free solutions and have the additional benefit of increased sustainability. In recent years, there have been several reviews on sustainable bio-adhesives for wood composites, based mainly on lignin, starch, tannins, and proteins (Pizzi 2006; Ferdosian et al. 2017; Hemmilä et al. 2017; Heinrich 2019; Solt et al. 2019). Bio-based adhesives are still in the laboratory development phase and suffer from several issues that hinder their application in industry. The most common limitations are the availability of raw materials, low reactivity and need for modification, high viscosity, slow curing, low water resistance, and greater costs in comparison with the conventional formaldehyde-based adhesives (Hemmilä et al. 2017). Depending on the biopolymer used, crosslinking with different, mostly synthetic, agents is required to achieve acceptable bonding performance. Solt et al. (2019) provided a thorough overview of the various crosslinking agents, their chemical structures, and toxicological information. Although there is a wish to develop bio-based crosslinkers, isocyanates seem to be the most viable formaldehyde-free candidates. The use of isocyanates is well established in North America, while a small amount of polymeric diphenylmethane diisocyanate (pMDI)-bonded particleboards (approximately $1 \%$ of the total annual production) is industrially available in Europe (Mantanis et al. 2018). Meanwhile, although mixtures of different biopolymers with pMDI have resulted in acceptable bonding performances of laboratory composites, it is questionable whether the addition of such compounds is really contributing to the adhesion (El Mansouri et al. 2007; Amaral-Labat et al. 2008; Pizzi 2014; Hemmilä et al. 2019b).

Currently, soy protein adhesives seem to have a lead over other bio-based counterparts. A thorough overview of soy-based adhesives can be found in Vnučec et al. (2017). Soy protein is a by-product of the soybean oil extraction process. Depending on the purification steps, it is available with different qualities, from the low-priced soy flour to the more expensive protein isolates. The world production of soybeans was estimated to be greater than 317 million $\mathrm{t}$ in 2015, and large quantities of soy flour can be used as wood adhesives, as they do not have any human food applications (Frihart 2015; Zhang et al. 2017). The adhesive performance of soy proteins is mainly affected by several factors such as the protein content, their structure, particle size, surface quality, viscosity, and $\mathrm{pH}$ (Frihart and Satori 2013; Frihart and Birkeland 2014). In general, drawbacks of soy protein adhesives are low water resistance, sensitivity to biological degradation, high viscosity at high solid content, and relatively low bonding strength of wood composites (Hemmilä et al. 2017). Denaturation of soy protein is performed with various chemicals, such as acids, alkalis, detergents, salts, and chaotropic agents, with the aim of exposing more polar groups for improved solubility and interaction via hydrogen bonds (Vnučec et al. 2017). Water resistance of soy protein adhesives is imparted by soy protein molecular modifications, i.e., grafting reactive groups onto protein molecules (Qin et al. 2013; Gui et al. 2016). These 
groups react with the polar groups of soy protein during hot pressing and form a crosslinked network in the course of curing (Kim and Sun 2014; Zhu and Damodaran 2014). The most developed crosslinker for soy protein is polyamidoamine-epichlorohydrin (PAE), while other protein crosslinkers include polyamides, polyethyleneimines (PEI), pMDI, and ketones (Li et al. 2004; Li 2007; Hamarneh et al. 2010; Gu and Li 2011). Natural materials such as tannins have also been tried as modifiers of soy-based resins (Ghahri and Pizzi 2018; Ghahri et al. 2018). Unlike the other biopolymers, there are several commercial adhesive systems (Kymene ${ }^{\circledR}$, SOYBABY ${ }^{\circledR}$, OZERO $^{\circledR}$, Soyad ${ }^{\mathrm{TM}}$, Prolia ${ }^{\mathrm{TM}}$ ) based on soy proteins, and they are used mainly for interior plywood and engineered wood flooring (Vnučec et al. 2017). Their acceptance for particleboards is limited, while the high amount of moisture introduced during adhesive application is considered a serious issue (Solt et al. 2019).

The present study proposed a novel bio-adhesive for particleboards based on natural materials: soy flour, magnesium oxide $(\mathrm{MgO})$, and a plant-derived enzymatic hydrolysate. $\mathrm{MgO}$ was used to facilitate the water solubility of soy flour (Jang and Li 2015), while its solubility and protein content could be further enhanced by adding the protein hydrolysate (McCarthy et al. 2013). Various properties of the natural adhesive were determined. Furthermore, the performance of particleboards using the adhesive in combination with PAE, the common synthetic crosslinker for proteins, was also investigated.

\section{EXPERIMENTAL}

\section{Chemicals}

Soybean flour (200 $\mu \mathrm{m}$ mesh) containing $38 \mathrm{wt} \%$ protein, $28 \mathrm{wt} \%$ carbohydrates, and $6 \mathrm{wt} \%$ moisture was purchased from Lameri S.p.A. (San Bassano, Italy). The oil content of soybean flour was about $30 \mathrm{wt} \%$, mainly made up of linoleic and linolenic acids. A water-free liquid hydrolysate obtained from enzymatic hydrolysis of an agricultural crop, having a density of $1300 \mathrm{~kg} / \mathrm{m}^{3}$ and a $\mathrm{pH}$ of 4.5, was supplied by NIS S.r.l. (Vallefoglia, Italy). The hydrolysate contained large amounts of fulvic acids (23\%) and proteins $(18.8 \%)$, with a small amount of humic acids (2\%). $\mathrm{MgO}$ was purchased from General Abrasivi S.r.l. (Carrara, Italy). Urea-formaldehyde (UF) resin with a solid content of 59\% was provided by Omnia Koll S.r.l. (Pesaro, Italy). The specific UF resin (OMNIAKOLL U208) is a self-hardening resin, formulated for use in flat presses, and the glue mixture is obtained simply by dispersing the resin in water $(2 / 3$ resin and $1 / 3$ water by weight). PAE with $12.5 \%$ solid content was purchased from Wuhan Golden Wing Industry \& Trade Co., Ltd (Wuhan, China).

\section{Natural Adhesive and Characterizations}

A natural adhesive was prepared by mixing the soy flour, $\mathrm{MgO}$, and plant hydrolysate at ambient temperature. The fulvic acids of the plant hydrolysate can potentially crosslink with the amino and fatty acids contained in the soy protein, while its proteins further enhance the protein content of the final adhesive. Fulvic acids are made up of a central nucleus derived from the assembly of aromatic, quinonic, and heterocyclic rings to which aliphatic chains are bound and have innumerable carboxylic, hydroxyl, phenolic, and alcoholic functional groups.

The extremely complex crosslinking function of this composite towards the linear chains of amino acid that are formed from protein substances can be added to the 
crosslinking of unsaturated fatty acids that are present in soy protein. Furthermore, numerous other components in the hydrolysate such as polysaccharides, polypeptides, lignins, ethers, carboxyls, quinones, peroxides, various combinations of benzene, acetal, ketal, lactol, and aliphatic compounds are all reactive and potential crosslinking substances. $\mathrm{MgO}$ in the presence of water forms magnesium hydrate and thus provides a strongly basic environment, which is necessary for the solubility of the soy flour and plant hydrolysate proteins and their interaction. It is known that when using protein from any source as an adhesive, denaturation is necessary to expose more polar groups for solubility and bonding via hydrogen bonds (Hemmilä et al. 2017). The proteins supplied through the plant hydrolysate are already denatured, and the denaturation of the proteins contained in the soy flour is supposed to occur by exposure to the high $\mathrm{pH}$ conferred by $\mathrm{MgO}$. Heat can speed up the process.

A first mixture was prepared by adding $\mathrm{MgO}(2.8 \mathrm{wt} \%)$ and then soy flour (38.9 $\mathrm{wt} \%)$ in deionized water $(44.4 \mathrm{wt} \%)$ with constant stirring. The plant hydrolysate (13.9 $\mathrm{wt} \%$ ) was added to prepare the final mixture by mixing for 1 min with the help of a handheld kitchen mixer. The final mixture was ground in a Retsch MM 400 (Retsch GmbH, Haan, Germany) ball mill for size reduction and homogenization, with 3 cycles of 2 min each at $30 \mathrm{~Hz}$. The total solids content of the resulting natural adhesive was $44 \%$, while its $\mathrm{pH}$ at $25^{\circ} \mathrm{C}$ was 8.7 .

Viscosity measurements of the natural adhesive were performed as a function of rotation speed (rotary stress) at $10{ }^{\circ} \mathrm{C}, 25{ }^{\circ} \mathrm{C}$, and $40{ }^{\circ} \mathrm{C}$ to represent different synthesis, application, and storage conditions. The rotational rheometer used (HR-1 Discovery Hybrid Rheometer with Trios v4.2.1.36612 software, both TA Instruments, New Castle, DE, USA) is a flat disc type with a diameter of $6 \mathrm{~cm}$, and the sample thickness between the two disks was $1 \mathrm{~mm}$. The viscosity was measured in triplicate.

The curing behavior of the natural adhesive was determined using differential scanning calorimetry (DSC) (Pyris 1 equipped with an Intracooler 2P cooling device, both Perkin Elmer, Norwalk, CT, USA). Differential scanning calorimetry was calibrated for temperature and heat flow using a pure sample of indium and zinc standards. Twenty $\mathrm{mg}$ of freshly blended adhesive mixture was heated from $-20{ }^{\circ} \mathrm{C}$ to $200{ }^{\circ} \mathrm{C}$ at a heating rate of $10{ }^{\circ} \mathrm{C} / \mathrm{min}$ under a nitrogen flow of $20 \mathrm{~mL} / \mathrm{min}$.

The thermal stability of the cured natural adhesive was tested using the Pyris 1 instrument (Perkin Elmer, Norwalk, CT, USA) with simultaneous thermogravimetric analysis (TGA) and differential thermal analysis (DTA). Powdered samples of $3 \mathrm{mg}$ were weighed in an alumina crucible and scanned from $30{ }^{\circ} \mathrm{C}$ to $500{ }^{\circ} \mathrm{C}$ at a heating rate of 10 ${ }^{\circ} \mathrm{C} / \mathrm{min}$ in a nitrogen environment. The weight change of the samples was recorded throughout.

Headspace gas chromatography-mass spectrometry (GC-MS) was performed to determine any emissions of harmful substances from the natural adhesive. The analyses were performed with a $6890 \mathrm{~N}$ gas chromatograph with a $7683 \mathrm{~N}$ autosampler coupled with a 5973N electronic impact mass detector by GC-MS instrument (Agilent Technologies, Santa Clara, CA, USA) at a temperature of $40^{\circ} \mathrm{C}$.

Air-dried thin films of the natural adhesive before and after treatment with the ball mill for size reduction and homogenization were placed on glass pieces and viewed with a Sigma 300 field emission scanning electron microscope (FESEM) (Carl Zeiss Microscopy $\mathrm{GmbH}$, Jena, Germany) to reveal details of the adhesive's morphology. 


\section{Particleboard Preparation and Testing}

Standard industry core and surface layer wood chips from mixed Scots pine (Pinus sylvestris) and Norway spruce (Picea abies) were oven-dried to $1.0 \% \pm 0.3 \%$ moisture content. The dried chips were then blended with weight combinations of the ground natural adhesive and PAE as a synthetic crosslinker of 0\%:100\%, 33\%:67\%, 50\%:50\%, 67\%:33\%, and 100\%:0\%. The adhesive solutions were sprayed onto the wood particles in a blender at a resin content (solid content) of $10 \mathrm{wt} . \%$ (calculated based on the weight of the ovendried wood particles). The moisture content of the blended particles with the adhesives ranged from $8 \%$ to $10 \%$. No wax or any other additives were applied for the manufacturing of the laboratory boards. The resinated chips were placed in a mould with dimensions of $200 \mathrm{~mm} \times 200 \mathrm{~mm}$ to produce 3-layer particleboards (60\% core share) with a thickness of $15 \mathrm{~mm}$ and a target density of $600 \mathrm{~kg} / \mathrm{m}^{3}$. The hand-formed mats were pressed using an inhouse built parallel plate hot-press with a pressing time of $18 \mathrm{~s} / \mathrm{mm}$ and a pressing temperature of $220^{\circ} \mathrm{C}$. One-step pressing schedule was followed and the pressure reached $30 \mathrm{~kg} / \mathrm{cm}^{2}$. Urea-formaldehyde-bonded boards were also prepared as above and served as controls.

After cooling to room temperature, the boards were trimmed and conditioned at 20 ${ }^{\circ} \mathrm{C} \pm 2{ }^{\circ} \mathrm{C}$ and $65 \% \pm 3 \%$ relative humidity before testing. The internal bond was tested according to EN 319 (1993), and thickness swelling (24 h) values were determined according to EN 317 (1993). Finally, the formaldehyde content of the particleboards was determined using the perforator method according to EN ISO 12460-5 (2016).

Statistical analysis was performed with the SPSS version 25.0 statistical software package (IBM Corp., Armonk, NY, USA). Analysis of variance (ANOVA) and Tukey's honest significant difference (HSD) test were performed on the particleboard testing data to indicate significant differences at a 95\% confidence level. Figures were drawn with the help of Microsoft Excel (Microsoft Corporation, Redmond, WA, USA).

\section{RESULTS AND DISCUSSION}

\section{Properties of the Natural Adhesive}

The viscosity of an adhesive is an important factor affecting the bond strength and is dependent on the size and shape of the adhesive's molecules, the solids content, and the amount of additives (Hong and Park 2017). The viscosity of the natural adhesive decreased when increasing the temperature at measurement from $10{ }^{\circ} \mathrm{C}$ to $40{ }^{\circ} \mathrm{C}$. The viscosity values at $10^{\circ} \mathrm{C}, 25^{\circ} \mathrm{C}$, and $40^{\circ} \mathrm{C}$ were, respectively, $1550 \mathrm{~Pa} \cdot \mathrm{s}, 510 \mathrm{~Pa} \cdot \mathrm{s}$, and $175 \mathrm{~Pa} \cdot \mathrm{s}$ at a shear rate of one rotation per second. These results suggested a good operability of the natural adhesive at $25{ }^{\circ} \mathrm{C}$, as viscosity is low enough for appropriate spreading and penetration into wood chips (Chen et al. 2017). However, the balance between viscosity and solids content is also important. The lower solids content of the natural adhesive (44\%) compare to that of UF resins (typically 66\%) indicated excess water that might cause steam-related internal voids (blows) during the particleboard manufacturing process (Dunky 1998). At each temperature level, the natural adhesive became thinner with the increase in shear force, and the viscosity decreased (Fig. 1). The natural adhesive could thus be characterised as a shear-thinning fluid showing non-Newtonian behaviour, as has been reported previously for soy protein adhesives (Zhang et al. 2005; Frihart and Satori 2013; Feng et al. 2018). 


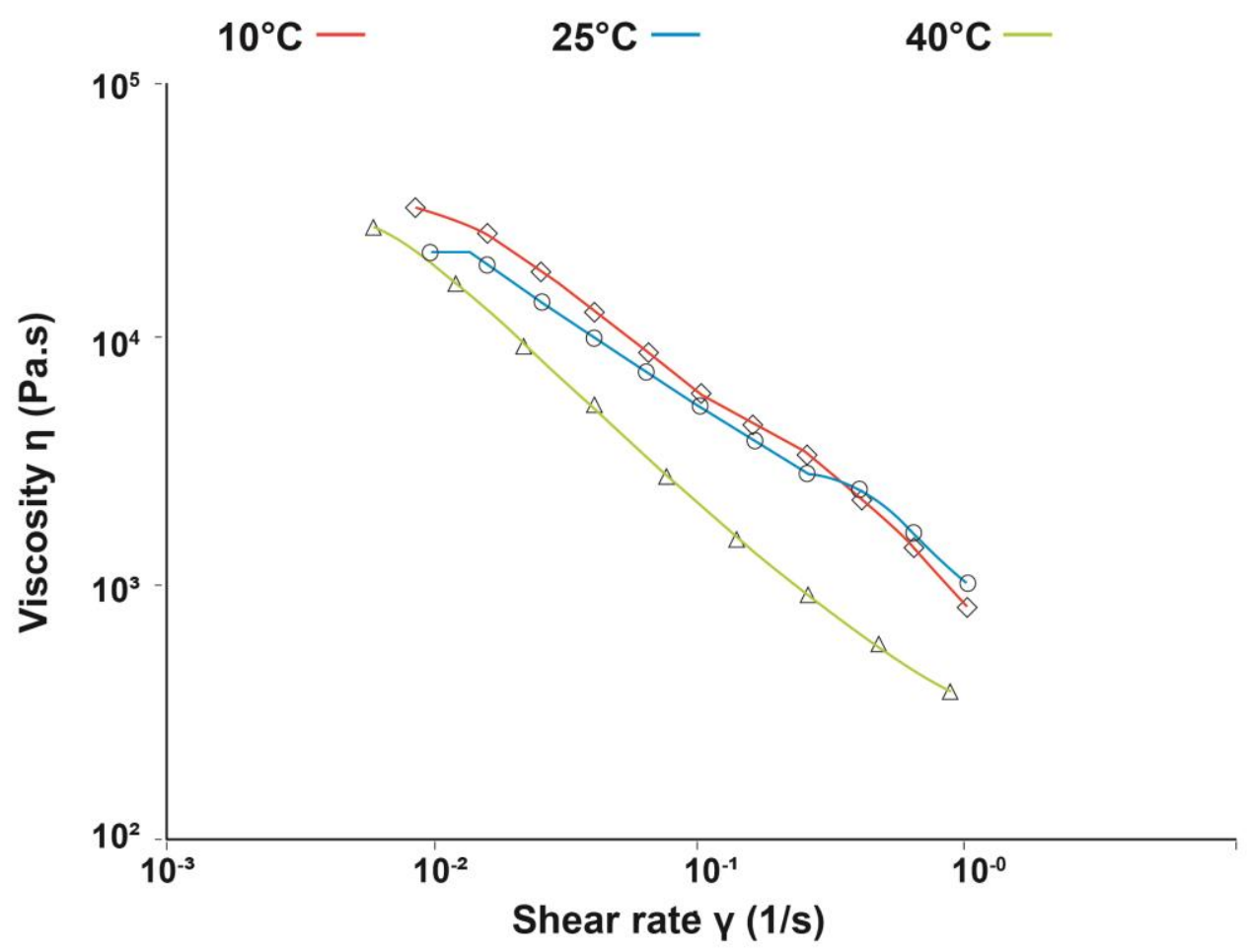

Fig. 1. Viscosity of the natural adhesive as a function of rotation speed (rotary stress) at $10{ }^{\circ} \mathrm{C}, 25$ ${ }^{\circ} \mathrm{C}$, and $40^{\circ} \mathrm{C}$

The DSC thermogram of the natural adhesive showed an intense endothermic signal $(\Delta H=424 \mathrm{~J} / \mathrm{g})$, mainly due to water evaporation (Fig. 2a). The maximum of the endothermic elimination of water signal was at $110^{\circ} \mathrm{C}$. In the temperature range of $130{ }^{\circ} \mathrm{C}$ to $240{ }^{\circ} \mathrm{C}$, no other endothermic or exothermic peak was noted. Thus, the natural adhesive appeared to be thermally stable and did not undergo any transformations. This result provided no evidence of any cross-linking among proteins or other polymeric chains $(\mathrm{Wu}$ et al. 2016). However, any exothermic signals associated with a possible cross-linking (i.e. involved in the glue hardening process) might have been covered by the intense water signal from $70^{\circ} \mathrm{C}$ to $130{ }^{\circ} \mathrm{C}$. Degradation processes occurred at temperatures greater than $250{ }^{\circ} \mathrm{C}$, while at approximately $350{ }^{\circ} \mathrm{C}$ both endothermic and exothermic decomposition and thermal degradation processes were observed. The heat flow profile of the natural adhesive at temperatures less than $220^{\circ} \mathrm{C}$ suggested that no thermal transitions existed that would lead to softening during the particleboard manufacturing process (O'Dell et al. 2013).

The TGA results in Fig. $2 \mathrm{~b}$ show that the natural adhesive was almost halved in mass in the temperature range of $30{ }^{\circ} \mathrm{C}$ to $130{ }^{\circ} \mathrm{C}$, mainly due to water loss. From $130{ }^{\circ} \mathrm{C}$ to $230{ }^{\circ} \mathrm{C}$, the sample showed thermal stability, as the weight remained unchanged. The adhesive thus showed no major degradation of its proteins and other major components, in accordance with the absence of signals in the DTA and DSC curves in the same temperature range. The mass loss observed from $230{ }^{\circ} \mathrm{C}$ to $500{ }^{\circ} \mathrm{C}$ was related to the progressive thermal degradation associated with the breaking of some bonds along with the degradation of the polymeric skeleton structure of the adhesive (Zhang et al. 2018). The thermal degradation was confirmed by the endothermic and exothermic signals at approximately $350{ }^{\circ} \mathrm{C}$ in the DTA curve (Fig. 2b). 
a

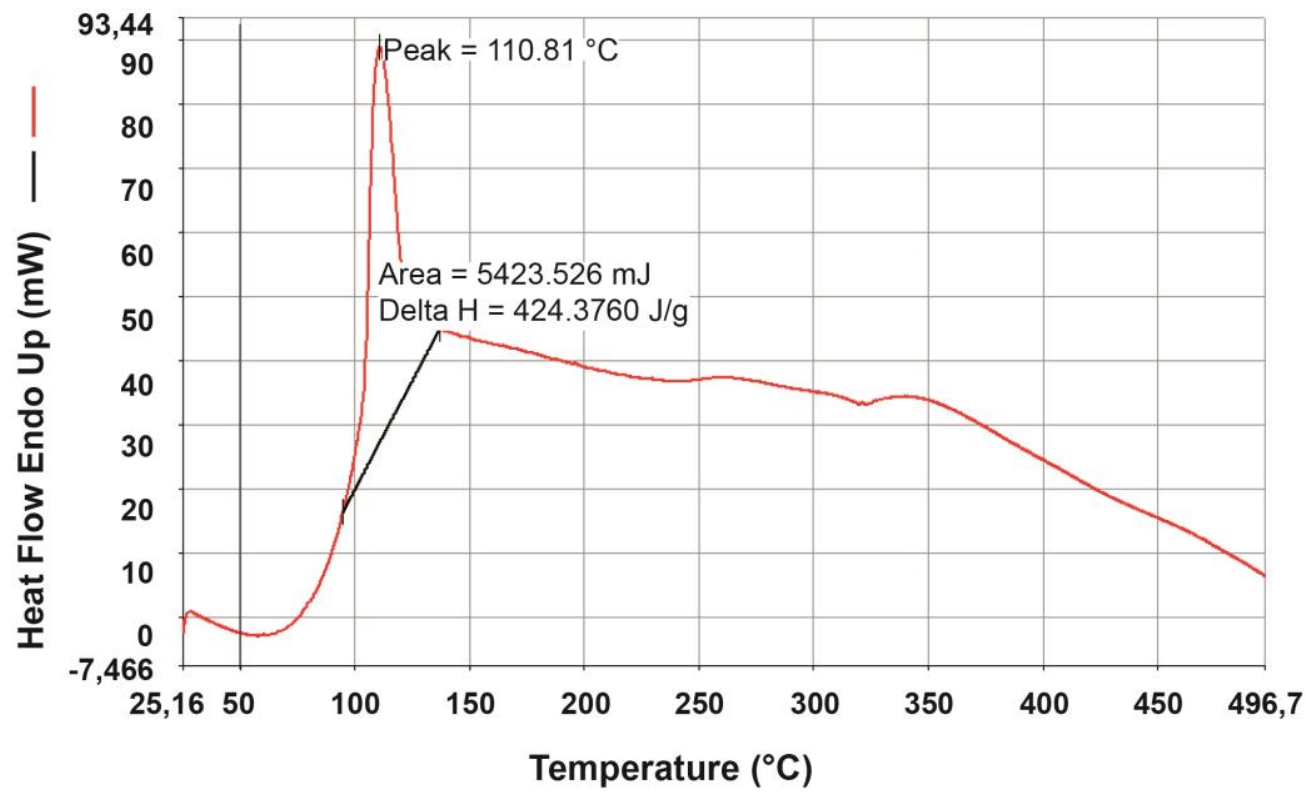

b

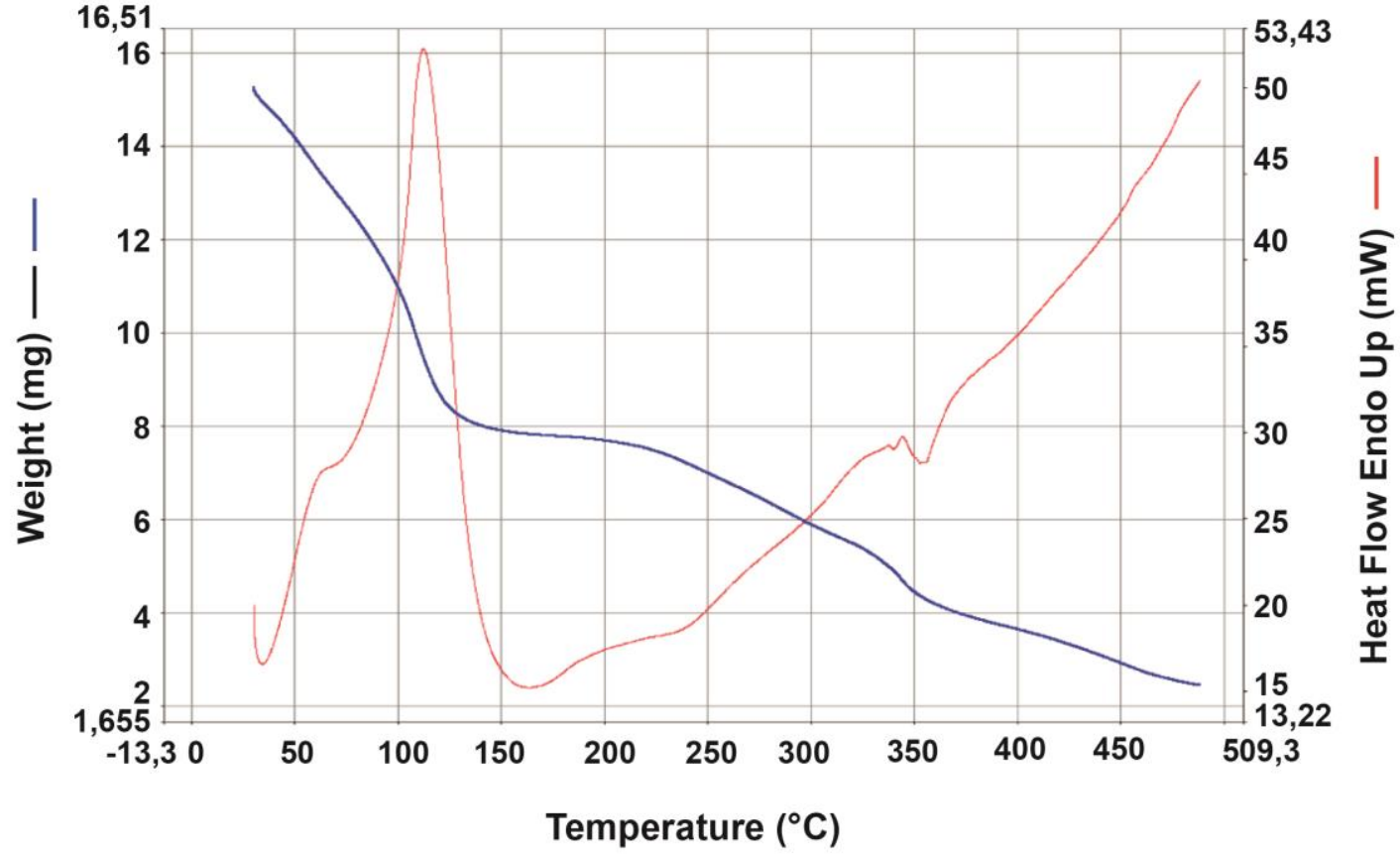

Fig. 2. (a) DSC and (b) TGA (blue curve) and DTA (red curve) results for the natural adhesive 
According to the headspace GC-MS results, no dangerous volatile substances were released from the natural adhesive in the thermal equilibrium condition at $40{ }^{\circ} \mathrm{C}$ (Fig. 3 and Table 1). The main volatile molecules detected in the headspace were alcohols and ketones (2-heptanone). The detected cyclotetrasiloxane and cyclopentasiloxane are cyclic dimethyl polysiloxane compounds and are commonly used in cosmetics. The Cosmetic Ingredient Review Expert Panel has concluded that these ingredients are safe in the present practices of use and concentration. In detail, available data on these compounds did not suggest skin irritation or sensitization potential, and it is not likely that dermal exposure would cause systemic exposure (Johnson et al. 2011).

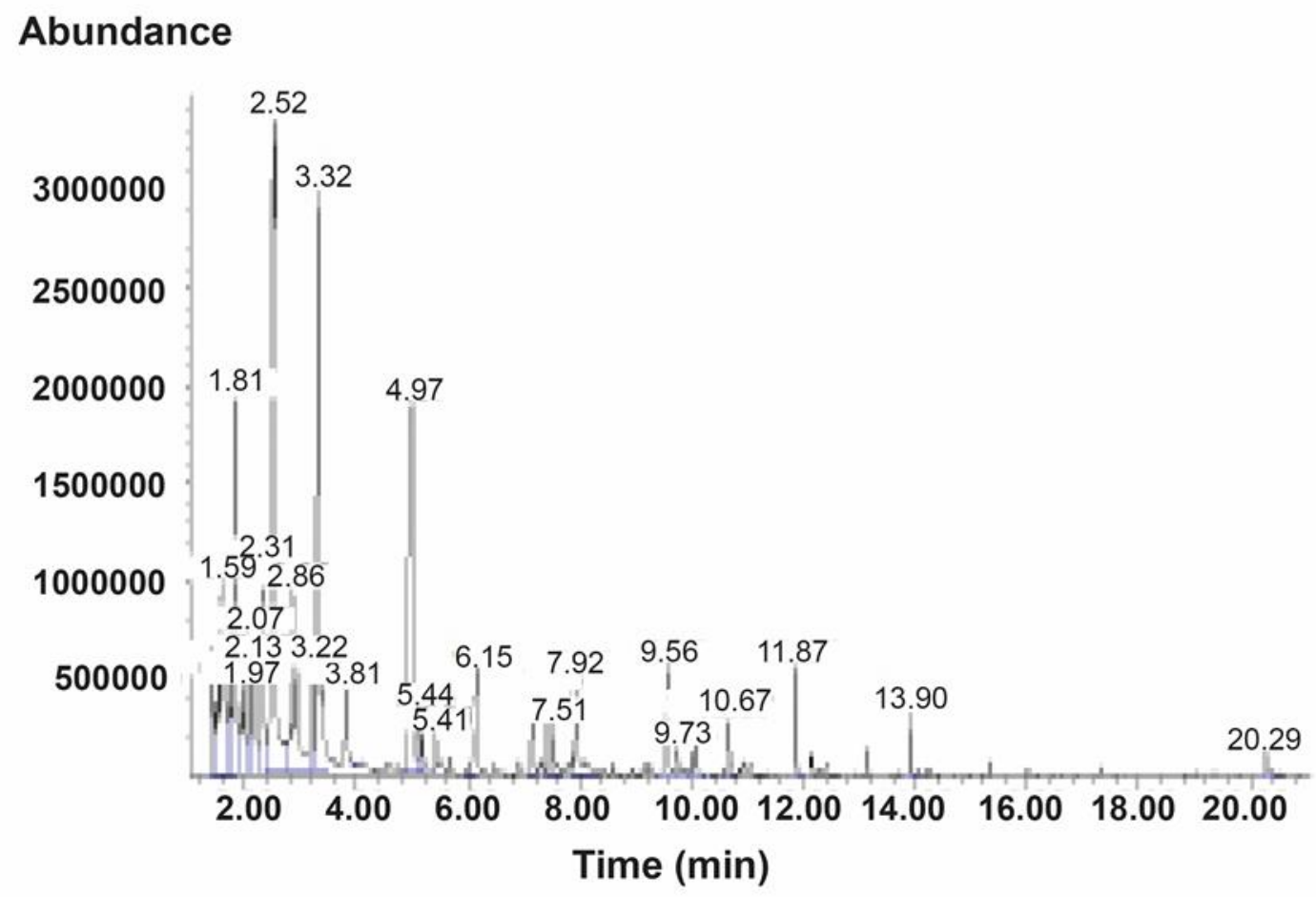

Fig. 3. Headspace GC-MS of the natural adhesive

Table 1. Compounds Identified and Correspondence in the GC-MS of the Natural Adhesive

\begin{tabular}{|c|c|c|c|}
\hline Retention Time $(\mathrm{min})$ & Compound Identified & CAS Number & Correspondence \\
\hline 1.73 & $1,3-$ Butanediol & $000107-88-0$ & $42 \%$ \\
\hline 1.81 & 1-Propanol, 2-methyl- & $000078-83-1$ & $95 \%$ \\
\hline 1.97 & Butanal, 2-methyl- & $000096-17-3$ & $49 \%$ \\
\hline 2.07 & 1-Penten-3-ol & $000616-25-1$ & $72 \%$ \\
\hline 2.31 & Silanediol, dimethyl- & $001066-42-8$ & $64 \%$ \\
\hline 2.52 & 1-Butanol, 2-methyl- & $001565-80-6$ & $78 \%$ \\
\hline 2.87 & 1-Pentanol & $000071-41-0$ & $90 \%$ \\
\hline 3.31 & Hexanal & $000066-25-1$ & $83 \%$ \\
\hline 4.97 & 1-Hexanol & $000111-27-3$ & $78 \%$ \\
\hline 5.40 & 2-Heptanone & $000110-43-0$ & $91 \%$ \\
\hline 6.14 & Oxime-, methoxy-phenyl- & $1000222-86-6$ & $90 \%$ \\
\hline 7.41 & 1-Octen-3-ol & $003391-86-4$ & $90 \%$ \\
\hline 7.92 & Cyclotetrasiloxane, octamethyl- & $000556-67-2$ & $91 \%$ \\
\hline 10.67 & Cyclopentasiloxane, decamethyl- & $000541-02-6$ & $94 \%$ \\
\hline
\end{tabular}


The surface morphologies of the cured adhesive samples with and without grinding of the adhesive mixture were examined by scanning electron microscopy. The results showed that the surfaces of the samples varied in coarseness (Fig. 4). Without grinding, one could see numerous granules with variable diameters ranging from $10 \mu \mathrm{m}$ to $30 \mu \mathrm{m}$ (Fig. 4a). Morphological details of a single grain are shown in Fig. 4b. The ground adhesive showed a smoother and more uniform surface with no granules (Fig. 4c). The finer particle size of the ground natural adhesive should provide more surface area and greater bond strength. Closer examination revealed the presence of very small air bubbles with diameters less than $0.5 \mu \mathrm{m}$ (Fig. $4 \mathrm{~d}$ ), which were probably due to the ball mill treatment. An indication that these structures are small bubbles and not granules is given by their perfectly circular shape.
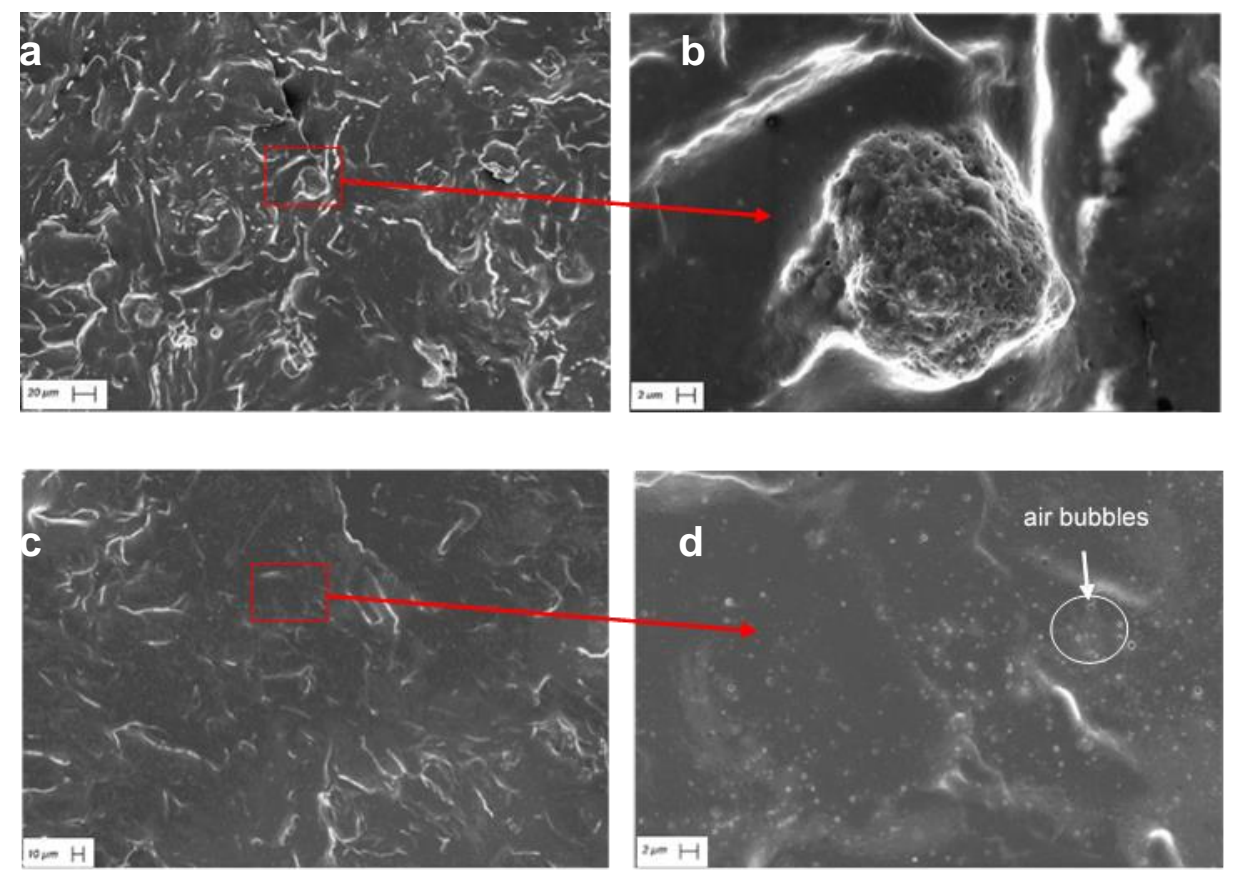

Fig. 4. Scanning electron micrographs on cured films of the natural adhesive ( $a$ and $b$ ) before and (c and d) after grinding with a ball mill for size reduction and homogenization, with (b and d) enlarged details of the surface morphologies

\section{Particleboards Bonded with the Natural Adhesive and PAE}

PAE is a known crosslinker that has helped soy protein adhesives gain commercial acceptance by improving their wet strength properties (Li 2007). PAE and soy protein molecules are capable of forming reversible ionic complexes at room temperature and within a $\mathrm{pH}$ range of 4 to 9 between the cationic azetidinium group of PAE and the anionic carboxyl group of soy protein before curing. The complexation interactions act as physical crosslinking that stabilizes the soy protein structure and increases its denaturation temperature and enthalpy. Further reactions between PAE and the proteins and wood can occur during curing (Zhong et al. 2007). Most research refers to interactions between PAE and soy protein isolates, while it has been reported that there is a different curing ability of soy flour from that from concentrate (Hunt et al. 2010). It has also been shown that curing with PAE and consequent interactions with wood and bond strength are little affected by types of soy flour with varying protein dispersibility indices (Frihart and Satori 2013). The intrinsic adhesive properties of the natural adhesive without added PAE were very inferior 
to UF in terms of internal bond strength (Fig. 5). The internal bond improved significantly with the addition of PAE, and differences were statistically significant with UF for each tested PAE load level (ANOVA, $\mathrm{p}<0.05 \%$ ). These results imply that PAE was necessary to impart adequate bond properties to the natural adhesive. A PAE-natural adhesive ratio of 33\%:67\% was sufficient in that respect. PAE resins bond well to wood, and thus PAE alone provided the greatest internal bond. The enhanced protein content of the natural adhesive offered by the plant-derived enzymatic hydrolysate should have contributed to a better interaction with PAE and wood.

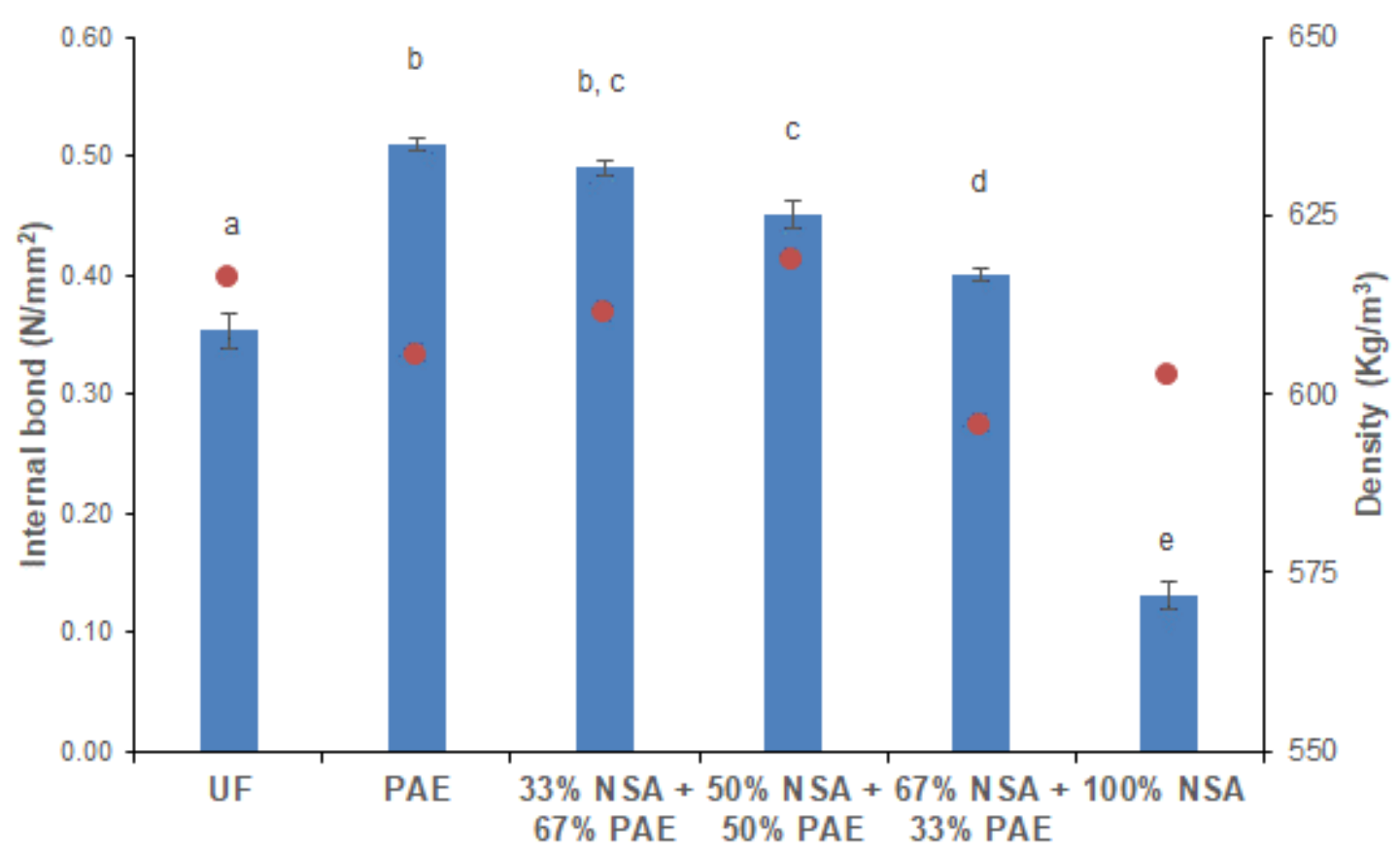

Fig. 5. Internal bond strength of particleboards produced with combinations of the natural adhesive (NSA) and PAE. The UF-bonded boards served as an additional reference. Error bars represent standard errors with $95 \%$ confidence intervals for means. Values labelled with different letters are statistically different according to ANOVA and Tukey's HSD test for $p<0.05 \%$. Note: mean density values of particleboards in each category are shown as red dots.

The poor water resistance of soy protein adhesives is a known problem that limits their application (Gao et al. 2012; Chen at al. 2015). The swelling results for the particleboards with the natural adhesive alone underperformed, as compared to the UFbonded boards (Fig. 6). Plywood panels bonded with a soy flour-MgO adhesive at weight ratios ranging from 10:1 to $1: 1$ have been reported to successfully pass a three-cycle soak test, which is the industrial water-resistance requirement for interior plywood (Jang and $\mathrm{Li}$ 2015). It was shown that close interactions between $\mathrm{MgO}$ and soy proteins, instead of soy carbohydrates, were responsible for the high water resistance of the soy flour-MgO adhesive. It was evident that the low amount of $\mathrm{MgO}(2.8 \mathrm{wt} \%)$ in the natural adhesive was not enough to fully provide the necessary water-resistance. As expected, a significant improvement in water resistance occurred when PAE was used, even at the lower percentage of $33 \%$. Swelling values were more or less similar for all natural adhesive-PAE combinations and were significantly lower than that of UF (ANOVA, p $<0.05 \%$ ). 


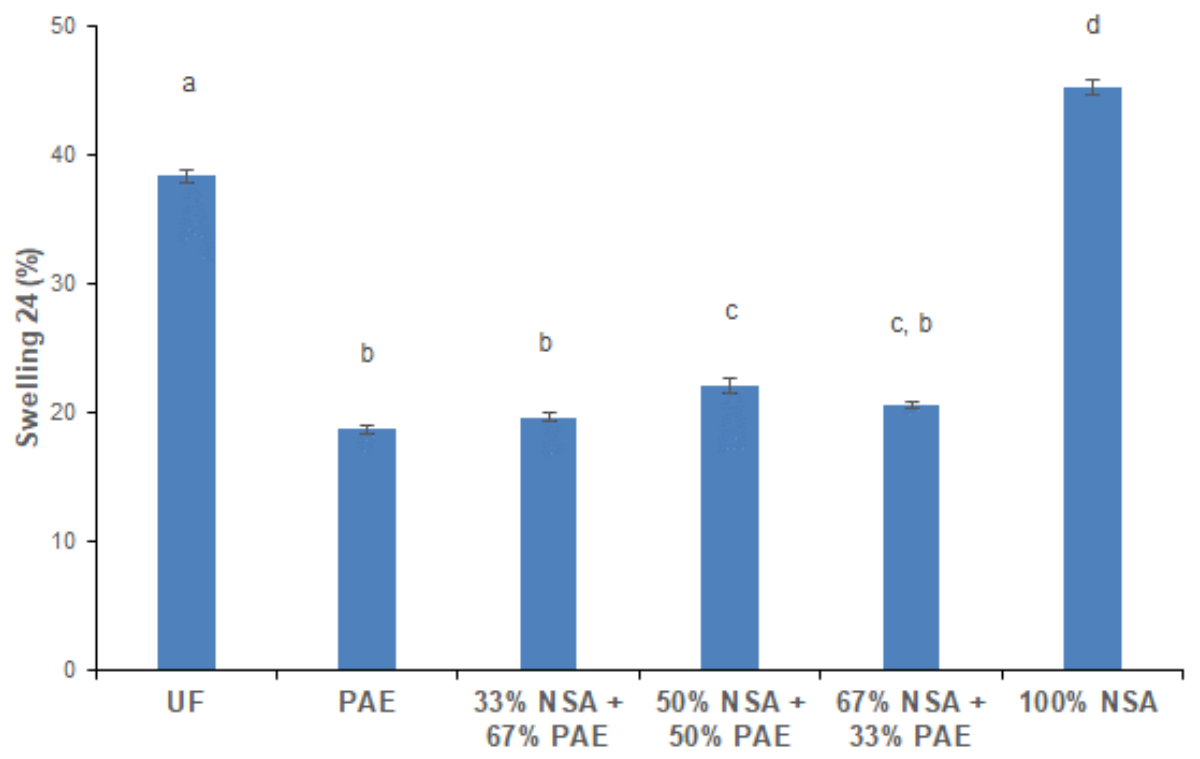

Fig. 6. Thickness swelling of particleboards produced with combinations of the natural adhesive (NSA) and PAE. The UF-bonded boards served as an additional reference. Error bars represent standard errors with $95 \%$ confidence intervals for means. Values labelled with different letters are statistically different according to ANOVA and Tukey's HSD test for $\mathrm{p}<0.05 \%$

As shown in Fig. 7, the particleboards with the natural adhesive and their combinations with PAE had significantly less formaldehyde content than the UF-bonded boards (ANOVA, p < $0.05 \%$ ). Formaldehyde-free wood particleboards with soybean protein adhesives have also been reported by others (Ferguson et al. 2014). The low detectable levels of formaldehyde associated with the natural adhesive/PAE-based particleboards were within natural wood levels (Hemmilä et al. 2019a).

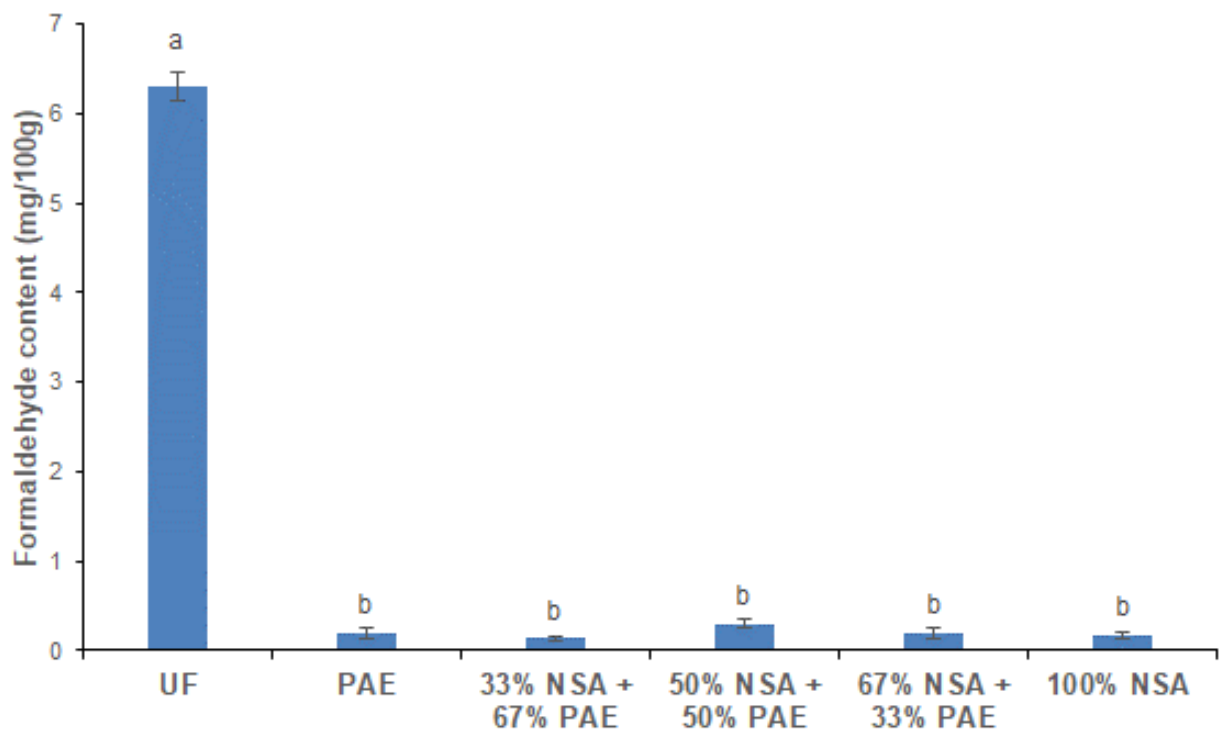

Fig. 7. Formaldehyde content of particleboards produced with combinations of the natural adhesive (NSA) and PAE according to the EN ISO 12460-5 (2016) standard (perforator method). The UF-bonded boards served as an additional reference. Error bars represent standard errors with $95 \%$ confidence intervals for means. Values labelled with different letters are statistically different according to ANOVA and Tukey's HSD test for $\mathrm{p}<0.05 \%$ 
Based on the overall results, the combination of the natural materials (soy flour, $\mathrm{MgO}$, and the plant-derived enzymatic hydrolysate) showed good potential for developing formaldehyde-free adhesives for particleboards. Further work on such formulations should focus on optimum levels of PAE as a crosslinker, appropriate solids content and viscosity, and reduced press times.

\section{CONCLUSIONS}

1. This study proposed a natural adhesive for particleboards based on soy flour, $\mathrm{MgO}$, and a liquid enzymatic hydrolysate of an agricultural crop. It was hypothesised that there would be good solubility and interaction of proteins from the soy flour and the plant hydrolysate under the basic conditions offered by $\mathrm{MgO}$ in water. By grinding the mixtures, an adhesive was prepared with $44 \%$ solids.

2. The natural adhesive showed the typical non-Newtonian behaviour of soy protein adhesives in terms of its viscosity as a function of rotation speed, along with appropriate operability for wood-based panels. The latter finding was also supported by the thermal analysis results.

3. No dangerous volatile substances were released from the natural adhesive according to headspace GC-MS, while scanning electron microscopy revealed a less coarse surface morphology of cured samples when the adhesive mixture was ground.

4. The natural adhesive required a synthetic crosslinker such as PAE, at one third of the final formulation, in order to achieve effective internal bond strength and resistance to swelling of the particleboards. All particleboards manufactured with various combinations of natural adhesive and PAE showed very low formaldehyde contents.

\section{ACKNOWLEDGMENTS}

Francesco Balducci would like to thank the University of Camerino and the companies Cosmob S.p.A. and NIS S.r.l. for providing prototyping and testing facilities support. Stergios Adamopoulos would like to thank the Kamprad Family Foundation for providing financial support (Project Grant No. 20160052, 2017-19).

\section{REFERENCES CITED}

Amaral-Labat, G. A., Pizzi, A., Gonçalves, A. R., Celzard, A., Rigolet, S., and Rocha, G. J. M. (2008). "Environment-friendly soy flour-based resins without formaldehyde," $J$. Appl. Polym. Sci. 108(1), 624-632. DOI: 10.1002/app.27692

Bundesministerium für Umwelt Naturschutz und nukleare Sicherheit (BUM) (2018). Bekanntmachung analytischer Verfahren für Probenahmen und Untersuching für die in Anlage 1 der Chemikalien-Verbotsverordnung genannten Stoffe und Stoffgruppen, Bundesanzeiger, BAnz, AT 26.11.2018 B2.

Chen, M., Chen, Y., Zhou, X., Lu, B., He, M., Sun, S., and Ling, X. (2015). "Improving water resistance of soy-protein wood adhesive by using hydrophilic additives," 
BioResources 10(1), 41-54. DOI: 10.15376/biores.10.1.41-54

Chen, N., Zheng, P., Zeng, Q., Lin, Q., and Rao, J. (2017). "Characterization and performance of soy-based adhesives cured with epoxy resin," Polymers-Basel 9(10). DOI: $10.3390 /$ polym9100514

Commission Regulation (EU) 2015/491 of 23 March 2015 amending Regulation (EU) No $605 / 2014$ amending, for the purposes of introducing hazard and precautionary statements in the Croatian language and its adaptation to technical and scientific progress, Regulation (EC) No 1272/2008 of the European Parliament and of the Council on classification, labelling and packaging of substances and mixtures, (https://eur-lex.europa.eu/legalcontent/EN/TXT/PDF/?uri=CELEX:32015R0491\&from=PL), Accessed December $10,2019$.

Dunky, M. (1998). "Urea-formaldehyde (UF) adhesive resins for wood," Int. J. Adhes. Adhes. 18(2), 95-107. DOI: 10.1016/S0143-7496(97)00054-7

Eastin, I., Brose, I., Maplesden, F., and Novoselov, I. (2015). "Wood-based panels," in: Forest Products: Annual Market Review 2014-2015, F. Guerrieri and C. F. Christian Friis Bach (eds.), UNECE/FAO, ECE/TIM/SP/39, United Nation Publications, pp. 65-75.

El Mansouri, N.-e., Pizzi, A., and Salvadó, J. (2007). "Lignin-based wood panel adhesives without formaldehyde," Holz Roh. Werkst. 65, 65-70. DOI:

10.1007/s00107-006-0130-z

EN 317 (1993). "Particleboards and fibreboards - Determination of swelling in thickness after immersion in water," European Committee for Standardization, Brussels, Belgium.

EN 319 (1993). "Particleboards and fibreboards - Determination of tensile strength perpendicular to the plane of the board," European Committee for Standardization, Brussels, Belgium.

EN ISO 12460-5 (2016). "Wood-based panels - Determination of formaldehyde release Part 5: Extraction method (called the perforator method), European Committee for Standardization, Brussels, Belgium.

EPA. (2017). Code of Federal Regulations (CFR) 40 CFR $§ 770$ on Formaldehyde Standards for Composite Wood Products Act, Title VI to the Toxic Substances Control Cct, TSCA; US Environmental Protection Agency.

Feng, C., Wang, F., Xu, Z., Sui, H., Fang, Y., Tang, X., and Shen, X. (2018). "Characterization of soybean protein adhesives modified by xanthan gum," Coatings 8(10). DOI: 10.3390/coatings8100342

Ferdosian, F., Pan, Z., Gao, G., and Zhao, B. (2017). "Bio-based adhesives and evaluation for wood composites application," Polymers-Basel 9(2). DOI: 10.3390/polym9020070

Ferguson, R. C., Mendon, S., Rawlins, J. W., and Thames, S. F. (2014). "Formaldehydefree wood composites from soybean protein adhesive," J. Renew. Mater. 2(3), 166172. DOI: 10.7569/JRM.2013.634133

Frihart, C. R., and Birkeland, M. J. (2014). "Soy properties and soy wood adhesives," in: Soy-Based Chemicals and Materials, R. P. Brentin (ed.), American Chemical Society, Washington, DC, pp. 167-192. DOI: 10.1021/bk-2014-1178.ch008

Frihart, C. R., and Satori, H. (2013). "Soy flour dispersibility and performance as wood adhesive,” J. Adhes. Sci. Technol. 27(18-19), 2043-2052. DOI:

10.1080/01694243.2012.696948 
Frihart, C. R. (2015). "Introduction to special Issue: Wood adhesives: Past, present, and future," Forest Prod. J. 65(1-2), 4-8. DOI: 10.13073/65.1-2.4

Ghahri, S. and Pizzi, A. (2018). "Improving soy-based adhesives for wood particleboard by tannins addition,” Wood Sci. Technol. 52, 261-279. DOI: 10.1007/s00226-0170957-y

Ghahri, S., Pizzi, A., Mohebby, B., Mirshokraie, A., and Mansouri, H. R. (2018). "Soybased, tannin-modified plywood adhesives," J. Adhes. 94(3), 218-237. DOI: 10.1080/00218464.2016.1258310

Gao, Q., Shi, S. Q., Li, J., Liang, K., and Zhang, X. (2012). "Soybean meal-based wood adhesives enhanced by modified polyacrylic acid solution," BioResources 7(1), 946956.

$\mathrm{Gu}, \mathrm{K}$., and Li, K. (2011). "Preparation and evaluation of particleboard with a soy flourpolyethylenimine-maleic anhydride adhesive," J. Am. Oil Chem. Soc. 88(5), 673-679. DOI: $10.1007 / \mathrm{s} 11746-010-1706-7$

Gui, C., Zhu, J., Zhang, Z., and Liu, X. (2016). "Research progress on formaldehyde-free wood adhesive derived from soy flour," in: Adhesives: Applications and Properties, A. Rudawska (ed.), IntechOpen, London, UK, pp. 187-200. DOI: 10.5772/65502

Hamarneh, A. I., Heeres, H. J., Broekhuis, A. A., Sjollema, K. A., Zhang, Y., and Picchioni, F. (2010). "Use of soy proteins in polyketone-based wood adhesives," Int. J. Adhes. Adhes. 30(7), 626-635. DOI: 10.1016/j.ijadhadh.2010.06.002

Heinrich, L. A. (2019). "Future opportunities for bio-based adhesives - Advantages beyond renewability," Green Chem. 21(8), 1866-1888. DOI: 10.1039/C8GC03746A

Hemmilä, V., Adamopoulos, S., Hosseinpourpia, R., and Ahmed, S. A. (2019b). "Ammonium lignosulfonate adhesives for particleboards with pMDI and furfuryl alcohol as crosslinkers," Polymers-Basel 11(10). DOI: 10.3390/polym11101633

Hemmilä, V., Adamopoulos, S., Karlsson, O., and Kumar, A. (2017). "Development of sustainable bio-adhesives for engineered wood panels - A review," RSC Adv. 7(61), 38604-38630. DOI: 10.1039/C7RA06598A

Hemmilä, V., Meyer, B., Larsen, A., Schwab, H., and Adamopoulos, S. (2019a). "Influencing factors, repeatability and correlation of chamber methods in measuring formaldehyde emissions from fiber- and particleboards," Int. J. Adhes. Adhes. 95. DOI: 10.1016/j.ijadhadh.2019.102420

Hong, M.-K., and Park, B.-D. (2017). "Effect of urea-formaldehyde resin adhesive viscosity on plywood adhesion," J. Korean Wood Sci. Technol. 45(2), 223-231. DOI: 10.5658/WOOD.2017.45.2.223

Hunt, C. G., O’Dell, J. L., and Frihart, C. R. (2010). "High-temperature performance of soy adhesives," in: Proceedings of the International Conference on Wood Adhesives, C. R. Frihart, C. G. Hunt, and R. J. Moon (eds.), Madison, WI, pp. 214-219.

International Agency for Research on Cancer (IARC) (2006). IARC Monographs on the Evaluation of Carcinogenic Risks to Humans, (https://monographs.iarc.fr/wpcontent/uploads/2018/06/mono88.pdf), Accessed December 2, 2019.

Jang, Y., and Li, K. (2015). "An all-natural adhesive for bonding wood," J. Am. Oil Chem. Soc. 92(3), 431-438. DOI: 10.1007/s11746-015-2610-y

Johnson, Jr., W., Bergfeld, W. F., Belsito, D. V., Hill, R. A., Klaassen, C. D., Liebler, D. C., Marks, Jr., J. G., Shank, R. C., Slaga, T. J., Snyder, P. W., et al. (2011). "Safety assessment of cyclomethicone, cyclotetrasiloxane, cyclopentasiloxane, cyclohexasiloxane, and cycloheptasiloxane," Int. J. Toxicol. 30, 149S-227S. DOI: $10.1177 / 1091581811428184$ 
Kim, M. J., and Sun, X. S. (2014). "Adhesion properties of soy protein crosslinked with organic calcium silicate hydrate hybrids," J. Appl. Polym. Sci. 131(17). DOI: 10.1002/app.40693

Li, K. (2007). "Formaldehyde-free lignocellulosic adhesives and composites made from the adhesives," U. S. Patent No. 7252735B2.

Li, K., Peshkova, S., and Geng, X. (2004). "Investigation of soy protein-Kymene ${ }^{\circledR}$ adhesive systems for wood composites," J. Am. Oil Chem. Soc. 81(5), 487-491. DOI: 10.1007/s11746-004-0928-1

Mantanis, G. I., Athanassiadou, E. Th., Barbu, M. C., and Wijnendaele, K. (2018). "Adhesive systems used in the European particleboard, MDF and OSB industries," Wood Mater. Sci. Eng. 13(2), 104-116. DOI: 10.1080/17480272.2017.1396622

McCarthy, A. L., O'Callaghan, Y. C., and O'Brien, N. M. (2013). "Protein hydrolysates from agricultural crops-Bioactivity and potential for functional food development," Agriculture 3(1), 112-130. DOI: 10.3390/agriculture3010112

O’Dell, J. L., Hunt, C. G., and Frihart, C. R. (2013). "High temperature performance of soy-based adhesives," J. Adhes. Sci. Technol. 27(18-19), 2027-2042. DOI: 10.1080/01694243.2012.696945

Pizzi, A. (2006). "Recent developments in eco-efficient bio-based adhesives for wood bonding: Opportunities and issues," J. Adhes. Sci. Technol. 20(8), 829-846. DOI: $10.1163 / 156856106777638635$

Pizzi, A. (2014). "Synthetic adhesives for wood panels," Rev. Adhes. Adhes. 2(1), 85126. DOI: $10.7569 /$ RAA.2013.097317

Qin, Z., Gao, Q., Zhang, S., and Li, J. (2013). "Glycidyl methacrylate grafted onto enzyme-treated soybean meal adhesive with improved wet shear strength," BioResources 8(4), 5369-5379. DOI: 10.15376/biores.8.4.5369-5379

Salthammer, T., Mentese, S., and Marutzky, R. (2010). "Formaldehyde in the indoor environment," Chem. Rev. 110(4), 2536-2572. DOI: 10.1021/cr800399g

Solt, P., Konnerth, J., Gindl-Altmutter, W., Kantner, W., Moser, J., Mitter, R., and van Herwijnen, H. W. G. (2019). "Technological performance of formaldehyde-free adhesive alternatives for particleboard industry," Int. J. Adhes. Adhes. 94, 99-131. DOI: 10.1016/j.ijadhadh.2019.04.007

Vnučec, D., Kutnar, A., and Goršek, A. (2017). "Soy-based adhesives for wood-bonding - A review," J. Adhes. Sci. Technol. 31(8), 910-931. DOI: 10.1080/01694243.2016.1237278

Wu, Z., Lei, H., Cao, M., Xi, X., Liang, J., and Du, G. (2016). "Soy-based adhesive cross-linked by melamine-glyoxal and epoxy resin," J. Adhes. Sci. Technol. 30(19), 2120-2129. DOI: 10.1080/01694243.2016.1175247

Zhang, J. T., Yang, X. Q., and Huang, L. X. (2005). "Changes of viscosity during preparation of soy protein isolate adhesives and their adhesive properties," China Oils Fats 30, 68-70.

Zhang, M., Zhang, Y., Chen, M., Gao, Q., and Li, J. (2018). "A high-performance and low-cost soy flour adhesive with a hydroxymethyl melamine prepolymer," PolymersBasel 10(8), 909. DOI: 10.3390/polym10080909

Zhang X., Zhu, Y., Yu, Y, and Song, J. (2017). "Improve performance of soy flour-based adhesive with a lignin-based resin," Polymers-Basel 9(7), 261. DOI: 10.3390/polym9070261 
Zhong, Z., Sun, X. S., and Wang, D. (2007). "Isoelectric pH of polyamideepichlorohydrin modified soy protein improved water resistance and adhesion properties," J. Appl. Polym. Sci. 103(4), 2261-2270. DOI: 10.1002/app.25388

Zhu, D., and Damodaran, S. (2014). "Chemical phosphorylation improves the moisture resistance of soy flour-based wood adhesive," J. Appl. Polym. Sci. 131(13). DOI: 10.1002/app.40451

Article submitted: November 19, 2019; Peer-review completed: January 15, 2020; Revised version received: January 26, 2020; Accepted: March 12, 2020; Published: March 18, 2020.

DOI: 10.15376/biores.15.2.3087-3102 